\title{
Tolerance to Citrus mosaic virus in Transgenic Trifoliate Orange Lines Harboring Capsid Polyprotein Gene
}

Toru Iwanami and Tokurou Shimizu, Department of Citrus Research, Okitsu, National Institute of Fruit Tree Science, Shimizu-Okitsu-Nakacho, Shizuoka, Shizuoka 424-0292, Japan; Takao Ito, Department of Citrus Research, Kuchinotsu, National Institute of Fruit Tree Science, Kuchinotsu, Nagasaki 859-2501, Japan; and Toshio Hirabayashi, Department of Citrus Research, Okitsu, National Institute of Fruit Tree Science

\begin{abstract}
Iwanami, T., Shimizu, T., Ito, T., and Hirabayashi, T. 2004. Tolerance to Citrus mosaic virus in transgenic trifoliate orange lines harboring capsid polyprotein gene. Plant Dis. 88:865-868.

Trifoliate orange plants (Poncirus trifoliata) were transformed with a binary vector containing the capsid polyprotein (pCP) gene of Citrus mosaic virus (CiMV) via Agrobacterium tumefaciens LBA4404. Transformation was performed on the epicotyl segments obtained from a young seedling that was grown in the dark. Southern blot hybridization analysis showed that the transgene was stable in the transgenic lines after regeneration and propagation by grafting. Transgenic lines were screened for tolerance to CiMV by mechanical inoculation. Infection was monitored 30,60, 90, and 120 days after inoculation by reverse transcription-polymerase chain reaction. The transgenic line 24 had the lowest infection rate $(7.1 \%)$ at 60 days after inoculation, in contrast to that of nontransgenic plants $(65.1 \%)$.The response of other lines to inoculation ranged from susceptibility to moderate tolerance.
\end{abstract}

Additional keywords: satsuma dwarf, nepovirus, soilborne disease

Citrus mosaic virus (CiMV) is a serious production constraint on citrus in Japan $(12,22,23)$. The infected trees grow poorly and often develop ringspot symptoms on the fruit, which drastically reduces the commercial value. CiMV is closely related to Satsuma dwarf virus $(12-14,22)$, which is a tentative member of the genus Nepovirus in the family Comoviridae (24). CiMV has a bipartite, positive-strand RNA genome consisting of RNA1 $(7.0 \mathrm{~kb})$ and RNA2 (5.4 kb), which are separately encapsidated in polyhedral particles about 28 $\mathrm{nm}$ in diameter (11). Both genomic RNAs are polyadenylated at the $3^{\prime}$ termini (11). Unlike definitive members of the genus Nepovirus, CiMV has two coat proteins (CP). The nucleotide sequences of the $3^{\prime}$ regions of RNA1 and RNA2 of CiMV isolate Ci-968 have been reported $(11,12)$. Both RNAs encode a polyprotein, and CPs are located at the C-terminus of the polyprotein encoded by RNA2 (11). The vector has not been identified (23). However, local natural spread, apparently through

Corresponding author: T. Iwanami

E-mail: tiwsw37@affrc.go.jp

Current address of T. Iwanami: National Agricultural Research Center for Kyushu Okinawa Region, Suya 2421, Nishigoshi, Kumamoto 861-1192, Japan.

Accepted for publication 9 April 2004.

Publication no. D-2004-0608-02R

(C) 2004 The American Phytopathological Society soil, has been observed in many citrus orchards, and once an orchard is infested, the disease may become permanently established (12). The persistent, soilborne nature of this virus prompted us to develop a tolerant rootstock.

The CP-mediated tolerance, which had been initially reported in transgenic tobacco that accumulated $\mathrm{CP}$ of Tobacco mosaic virus (1), has been demonstrated in many other plants (7). Tolerance against viruses like comoviruses, which have two capsid proteins, has been achieved by expressing the polyprotein that contains the two capsid proteins $(5,18,20)$.

In this paper, we report our attempt to obtain tolerance to CiMV by expressing the $\mathrm{CP}$ polyprotein $(\mathrm{pCP})$ in trifoliate orange (Poncirus trifoliata), which is a major rootstock in citriculture in Japan.

\section{MATERIALS AND METHODS}

Construction of the binary plasmid vector ( $\mathrm{pBCiCP)}$ and plant transformation. The plasmid CIK116, which contained cDNA for the $3^{\prime}$ region of CiMV RNA2, had been constructed previously (11) and was used as the source of the pCP gene. The $\mathrm{pCP}$ gene consists of a set of larger and smaller $\mathrm{CP}$ genes. The DNA fragment of the pCP gene was amplified from the plasmid CIK116 using a set of forward (CCPFW1, 5'-cctctagaacaatggg atttacagaat-3') and reverse (CCPRV1, 5'tgtgagctcacgtaaaggtccggtgg- $3^{\prime}$ ) primers. The forward and reverse primers contain the $X b a \mathrm{I}$ and $S a c \mathrm{I}$ restriction sites at their termini (underlined), respectively. The forward primer contained the initiation codon for the expression of pCP. The resulting DNA fragment was ligated into the plasmid pUC19 to produce the plasmid pCCP1. An expression vector was constructed by replacing the $\beta$-glucuronidase (GUS) gene in the binary vector pBE2113GUS (16) with the cloned pCP sequence (Fig. 1). The resulting plasmid was designated $\mathrm{pBCiCP}$ and was introduced into Agrobacterium tumefaciens strain LBA4404. The plasmid $\mathrm{pBCiCP}$ had no viral protease, and the transgene was supposed to express a polyprotein without cleavage into larger and smaller $\mathrm{CPs}$ in plants.

Plant transformation, screening, and propagation. Transformation and regeneration of trifoliate orange plants were conducted as previously reported (15). The regenerated shoots on a selection medium containing Kanamycin $(200 \mu \mathrm{g} / \mathrm{ml})$ were screened for the presence of transgene by polymerase chain reaction (PCR) amplification using a primer set of CCPFW72 (5'tccttctatgcatggtctctcact- $3^{\prime}$ ) and CCPRV926 (5'-tgagagtagtgatcagcgcttg- $\left.3^{\prime}\right)$ after extraction with cetyltrimethylammonium bromide (CTAB), as reported previously (17). Amplification was carried out for 40 cycles of $94^{\circ} \mathrm{C}$ for $30 \mathrm{~s}, 63^{\circ} \mathrm{C}$ for $30 \mathrm{~s}$, and $72^{\circ} \mathrm{C}$ for $90 \mathrm{~s}$, after the initial denaturation at $94^{\circ} \mathrm{C}$ for $4 \mathrm{~min}$. The plants, which were positive in PCR screening, were grafted to etiolated sour orange seedlings and subsequently side-grafted to rough lemon rootstock to promote vigorous growth. After the second grafting, the transformants were grown in a closed-system greenhouse, which was maintained at a constant $25^{\circ} \mathrm{C}$.

Mechanical inoculation with CiMV. Etrog citron cuttings infected with CiMV isolate Ci-968K (11) were used as the inoculum source. Five to 10 plants of each transgenic and nontransgenic trifoliate orange were inoculated mechanically by either stem-slashing (8) or conventional grafting. For stem-slash inoculation, the young, tender leaves of the CiMV-infected Etrog citron were macerated and diluted $1: 5(\mathrm{wt} / \mathrm{vol})$ in neutral phosphate buffer $(0.1 \mathrm{M})$ containing $0.1 \% \quad(\mathrm{vol} / \mathrm{vol}) \quad 2$ mercaptoethanol. The stem of the trifoliate orange was slashed 50 times with a knife that was immersed in the extract after every 10 cuttings. For graft inoculation, blind buds were excised from a CiMV- 
infected Etrog citron plant and inserted into the stem of the trifoliate orange.

Enzyme-linked immunosorbent assay (ELISA) detection. Tender, immature leaves from transgenic and nontransgenic trifoliate orange were assayed by doubleantibody sandwich ELISA (DAS-ELISA) (4) using CiMV polyclonal antibody, which had been raised against an isolate Ci-968K and used routinely in our labora- tory (13). Typically, two samples were taken from a tree, and two wells in the ELISA plate were used for each extract. Leaves were macerated in 1:10 (wt/vol) volumes of citrate buffer ( $\mathrm{pH}$ 6.5) containing $0.1 \%$ 2-mercaptoacetic acid, and each well of the plate was filled with $200 \mu \mathrm{l}$ of the extract. IgG $(1 \mathrm{mg} / \mathrm{ml})$ for coating ELISA plate and alkaline phosphate-IgG conjugates, which had been conjugated

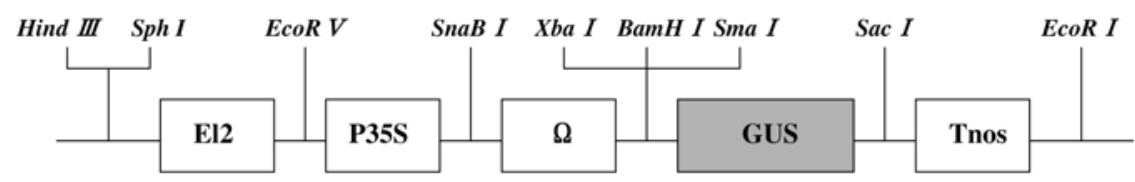

pBE2113-GUS



Fig. 1. Restriction map of the binary plasmid vector. pBE2113-GUS, a recombinant binary transformation vector (16); El2, two tandem repeats of the upstream sequence of Cauliflower mosaic virus (CaMV) 35S promoter; P35S, upstream sequence of CaMV 35S promoter; $\Omega$, 5'-untranslated sequence of Tobacco mosaic virus; GUS, $\beta$-glucuronidase gene; Tnos, polyadenylation signal of the gene for nopaline synthase in the Ti plasmid (16); pBCiCP, a recombinant binary transformation vector prepared in this study; CiMVpCP, LCP, and SCP represent genes for coat protein polyprotein, large coat protein, and small coat protein of Citrus mosaic virus.

324252627283031323539454647485156636874

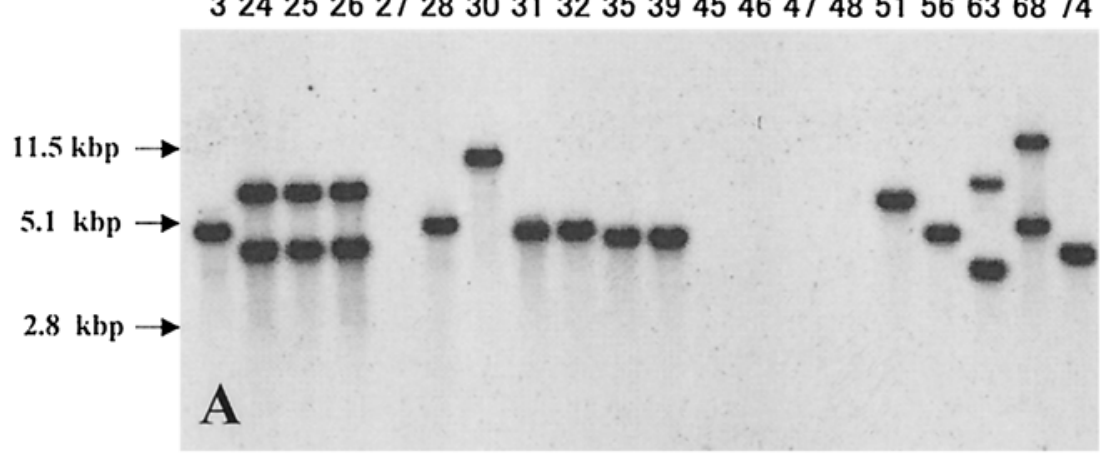

\section{W}



Fig. 2. Southern blot hybridization analysis of DNA from lines of trifoliate oranges, transformed with coat protein polyprotein gene of Citrus mosaic virus (CiMV). Total DNA from the transgenic lines was double-digested with HindIII and XbaI in A, and with SphI and EcoRI in B, and probed with the CiMV pCP gene probe. Lane numbers correspond to the transgenic lines of trifoliate orange, and W indicates DNA from nontransformed wild-type trifoliate orange. 
chloro)-tricyclo[3.3.1.1]decan]-4-yl) phenyl phosphate (CDP-star) containing ECL system (ECL, Amersham Bioscience).

Reverse transcription (RT)-PCR for monitoring CiMV after challenge inoculation. After transgenic plants were mechanically inoculated with CiMV, the infection was monitored by RT-PCR for up to 120 days after inoculation (dai). Since both forward and reverse primers were designed to be specific to RNA1, the RTPCR product was considered to be amplified from viral RNA, not from transcript of pCP transgenes, which originated from RNA2.

Total RNA was isolated from $0.5 \mathrm{~g}$ of young tender leaf tissue as reported previously $(2,3)$, and the final RNA pellet was dissolved in $100 \mu \mathrm{l}$ of TE buffer. First strand cDNA was synthesized from $1 \mu \mathrm{l}$ of RNA sample added to $20 \mu \mathrm{l}$ of the reverse transcription mixture containing $1 \times$ first strand buffer $(10 \mathrm{mM}$ Tris-HCL, $50 \mathrm{mM}$ $\mathrm{KCl}, 2.5 \mathrm{mM} \mathrm{MgCl} 2, \mathrm{pH} 8.3), 1 \mathrm{mM}$ of each dNTP, 20 units of RNase inhibitor, 50 units of MuLV reverse transcriptase, and 1 $\mu \mathrm{M}$ of reverse primer (5'-gttgcaaagcag ggcatctgctac- $3^{\prime}$ ), which is complementary to the $3^{\prime}$ region of CiMV RNA1. The reaction mixture was incubated at $42^{\circ} \mathrm{C}$ for 30 min and added to a PCR reaction mixture to a final volume of $100 \mu \mathrm{l}$, containing $1 \times$ PCR buffer (10 mM Tris-HCL, $50 \mathrm{mM}$ $\mathrm{KCl}, 2.5 \mathrm{mM} \mathrm{MgCl} 2$, pH 8.3), $200 \mu \mathrm{M}$ of each dNTP, 2.5 units of AmpliTaq DNA polymerase (Applied Biosystems, Foster City, CA), and $1 \mu \mathrm{M}$ each of reverse and forward primer (5'-gaagaggttgatttcctg aagcgg- $\left.3^{\prime}\right)$. The amplifications were performed in a DNA Thermal Cycler 9600 (Applied Biosystems) for 40 cycles under the following conditions: $30 \mathrm{~s}$ at $94^{\circ} \mathrm{C}, 30$ $\mathrm{s}$ at $60^{\circ} \mathrm{C}$, and $60 \mathrm{~s}$ at $72^{\circ} \mathrm{C}$.

\section{RESULTS}

Integration of the CiMV CP genes in trifoliate orange. After a typical transformation experiment on trifoliate orange, eight of 144 epicotyl segments were resistant to Kanamycin, and transgene was detected by PCR from five of the eight lines regenerated on Kanamycin-containing medium. Transformation was conducted several times, and 32 candidates were established. After grafting, the established transgenic lines grew vigorously in a closed greenhouse, and they were about $10 \mathrm{~mm}$ in diameter just above the graftunion in 15 months. Southern blot hybridization after digestion of the plant genomic DNA with HindIII and XbaI, which cuts upstream region of the transgene (Fig. 1), is shown in Figure 2A. Under these conditions, the number of the bands should correspond to the copies of transgene. The results indicated that one to three copies of pCP gene were present in the plant genome except for lines 27, 45, 46, 48, and 97. Transgenes were not detected from six transformant candidates (lines 27, 45, 46,
47, 48, and 97) by Southern blot hybridization (Fig. 2A), suggesting false-positive results in the PCR assay on these lines. After excluding lines that have no transgene, a second Southern hybridization test was conducted to estimate the size of the transgene. To do this, the genomic DNA of the transgenic lines were digested with SphI and EcoRI to cut both ends of the transgene (Fig. 1). The results showed that the blot of expected size (4.6 kbp) was present in the transgenic lines except for lines 3, 28, and 63 (Fig. 2B). The transgenic lines 24,25 , and 26 were considered to be identical, judging from the similarity of the hybridization bands (Fig. 2A) and their origin from the same regenerated shoot. Furthermore, we concluded that the transgenic lines 3 and 28 were identical, and likewise for the transgenic lines 31 and 32. Finally, 22 transgenic lines listed in Table 1 were established and used for further analysis. The expression level of the transgenes in these lines was estimated by DAS-ELISA using anti-CiMV antiserum, and summarized in Table 1. Since the ELISA was conducted on the transgenic plants before inoculation with CiMV, the values are interpreted as the expression level of pCP transgene. The ELISA values for the established transgenic plants after subtraction of background ranged from 0.006 to $0.960 A_{405 \mathrm{~nm}}$, suggesting different levels of expression of pCP gene among the transgenic lines (Table 1).

Response to virus inoculation. The results of stem-slash inoculations of the transgenic trifoliate orange plants are summarized in Table 1. In a typical inoculation test, five replications were used for each transgenic line, while 10 seedlings of trifoliate orange, which were as old as transformed lines, were inoculated as controls.

Differences in response to CiMV inoculation between transformed and nontransformed plants were most apparent at 60 dai (Table 1). Using RT-PCR amplification, CiMV was detected in only one of 14 plants $(7.1 \%)$ in the transgenic line 24 , in contrast to 28 of 43 nontransgenic plants (65.1\%). Also, fewer than 2 of 5 or 10 plants $(20 \%$ or less) were infected in transgenic lines 31, 80, and 83 at 60 dai. Establishing a threshold of $20 \%$ at 60 dai, these lines were considered tolerant to CiMV infection. Differences between transgenic line 24 and nontransgenic trifoliate orange were apparent up to 120 dai, while transgenic line 80 , which showed difference at 60 dai, were all infected at 90 dai. CiMV was detected at high frequencies in transgenic lines 74, 91, 93, and 95, and these lines were considered susceptible. On the basis of low infection rates, line 24 was considered the most tolerant, in spite of lower level expression of $\mathrm{pCP}$, as estimated by ELISA. Overall, tolerance to CiMV infection was not correlated with level of pCP expression (Table 1).

When graft-inoculation was tried, all of the tested transgenic lines and nontransgenic controls were infected at 60 dai, as determined by RT-PCR (data not shown).

Table 1. Double-antibody sandwich enzyme-linked immunosorbent assay (DAS-ELISA) of transgenic trifoliate orange lines and response to inoculation with Citrus mosaic virus (CiMV) at 60, 90, and 120 days after inoculation (dai)

\begin{tabular}{|c|c|c|c|c|}
\hline Line & $\begin{array}{c}\text { DAS-ELISA values } \\
(405 \mathrm{~nm})\end{array}$ & 60 dai & 90 dai & 120 dai \\
\hline Control & 0.017 & $28 / 43^{z}$ & $34 / 43$ & $42 / 43$ \\
\hline 24 & 0.006 & $1 / 14$ & $3 / 14$ & $4 / 14$ \\
\hline 28 & 0.021 & $4 / 10$ & $7 / 10$ & $10 / 10$ \\
\hline 30 & 0.080 & $2 / 5$ & $4 / 5$ & $4 / 5$ \\
\hline 31 & 0.960 & $0 / 5$ & $2 / 5$ & $2 / 5$ \\
\hline 35 & 0.952 & $4 / 10$ & $7 / 10$ & $7 / 10$ \\
\hline 39 & 0.641 & $3 / 9$ & $4 / 9$ & $8 / 9$ \\
\hline 51 & 0.281 & $2 / 5$ & $3 / 5$ & $5 / 5$ \\
\hline 56 & 0.933 & $2 / 5$ & $4 / 5$ & $5 / 5$ \\
\hline 63 & 0.060 & $2 / 5$ & $4 / 5$ & $5 / 5$ \\
\hline 68 & 0.557 & $2 / 5$ & $5 / 5$ & $5 / 5$ \\
\hline 74 & 0.504 & $4 / 5$ & $4 / 5$ & $5 / 5$ \\
\hline 80 & 0.521 & $0 / 5$ & $5 / 5$ & $5 / 5$ \\
\hline 83 & 0.810 & $1 / 10$ & $5 / 10$ & $6 / 10$ \\
\hline 87 & 0.814 & $2 / 10$ & $4 / 10$ & $6 / 10$ \\
\hline 89 & 0.059 & $1 / 5$ & $4 / 5$ & $4 / 5$ \\
\hline 90 & 0.704 & $2 / 5$ & $5 / 5$ & $5 / 5$ \\
\hline 91 & 0.332 & $3 / 5$ & $3 / 5$ & $5 / 5$ \\
\hline 92 & NT & $3 / 3$ & $3 / 3$ & $3 / 3$ \\
\hline 93 & 0.092 & $3 / 5$ & $5 / 5$ & NT \\
\hline 95 & 0.580 & $3 / 5$ & $3 / 5$ & $5 / 5$ \\
\hline 96 & 0.951 & $1 / 2$ & $2 / 2$ & $2 / 2$ \\
\hline 98 & 0.945 & $2 / 5$ & $5 / 5$ & $5 / 5$ \\
\hline
\end{tabular}

y DAS-ELISA values are the average of optical density readings at four wells after subtraction of background. DAS-ELISA was conducted on the transgenic plants before inoculation with CiMV, and the values are interpreted as the expression level of the coat protein polyprotein transgene.

${ }^{\mathrm{z}}$ Number of reverse-transcription polymerase chain reaction positive plants/number of inoculated plants. 


\section{DISCUSSION}

The efficiency of transformation in citrus is low, and few agriculturally important genes have been transferred. To our knowledge, the transfer of a viral gene to citrus has been successfully conducted using the $\mathrm{CP}$ gene of Citrus tristeza virus (CTV; 6,9). Satsuma mandarin, a major citrus in Japan, Korea, and some parts of China, is tolerant to CTV and susceptible to CiMV. The results presented in this paper suggested that the $\mathrm{pCP}$ gene of CiMV was successfully transformed into trifoliate orange rootstock. The inoculated epicotyl was transformed at a frequency of 2.1 to $4.6 \%$ (data not shown). The stability of the transgene was shown, for most of the lines, by Southern hybridization analysis on the plants that were propagated by grafting after transformation and regeneration. In lines 3, 28, and 63, the transgene was larger than the expected size. We speculate that the transgene is partially dimers in these transgenic lines.

Lines $24,31,80$, and 83 of trifoliate orange transformed with pCP of CiMV exhibited tolerance. There was little correlation between tolerance and the level of transgene expression. In this study, the expression of transgene was estimated only by ELISA. Our trial to detect $\mathrm{pCP}$ by Western blotting failed (data not shown). It was not clear that intact pCP accumulates in lines that showed high values in ELISA. A lack of correlation between tolerance and the transgene protein level has been observed in reports on genetically engineered tolerance to RNA viruses $(19,21)$. In some of these cases, the tolerance has been referred to as RNA-mediated (19). The tolerance mechanism to $\mathrm{CiMV}$ in transgenic trifoliate orange lines needs to be confirmed by further experiments.

We are now planning to plant the most promising transgenic lines in a CiMVinfested field, and to evaluate their tolerance to CiMV infection under natural conditions.

\section{ACKNOWLEDGMENTS}

We thank Y. Ohashi for providing the binary vector pBE2113-GUS, and C. Azeyanagi for tech- nical assistance. We are grateful to $\mathrm{M}$. Hilf for critical reading of the manuscript.

\section{LITERATURE CITED}

1. Bendahmane, M., and Beachy, R. N. 1999. Control of tobamovirus infections via pathogen-derived resistance. Adv. Virus Res. 53:369-386.

2. Chomczynski, P. 1993. A reagent for the single-step simultaneous isolation of RNA, DNA and proteins from cell and tissue samples. Biotechniques 15:532-534.

3. Chomczynski, P., and Sacchi, N. 1987. Singlestep method of RNA isolation by acid guanidinium thiocyanate-phenol-chloroform extraction. Anal. Biochem. 162:156-159.

4. Clark, M. F., and Adams, A. N. 1977. Characteristics of the microplate methods of enzymelinked immnosorbent assay for the detection of plant viruses. J. Gen. Virol. 34:475-483.

5. Di, R., Purcell, V., Collins, G. B., and Ghabrial, S. A. 1996. Production of transgenic soybean lines expressing the bean pod mottle virus coat protein precursor gene. Plant Cell Rep. 15:746-750.

6. Dominguez, A., Hermoso de Mendoza, A., Guerri, J., Cambra, M., Navarro, L., Moreno, P., and Pena, L. 2002. Pathogen-derived resistance to Citrus tristeza virus (CTV) in transgenic mexican lime (Citrus aurantifolia (Christ.) Swing.) plants expressing is $p 25$ coat protein gene. Mol. Breed. 10:1-10.

7. Fichen, J. H., and Beachy, R. N. 1993. Genetically engineered protection against viruses in transgenic plants. Annu. Rev. Microbiol. 47:739-763.

8. Garnsey, S. M., and Whidden, R. 1973. Efficiency of mechanical inoculation procedures for citrus exocortis virus. Plant Dis. Rep. 57:886-889.

9. Gutierrez, E. M., Luth, D., and Moore, G. A. 1997. Factors affecting Agrobacteriummediated transformation in Citrus and production of sour orange (Citrus aurantium L.) plants expressing the coat protein gene of citrus tristeza virus. Plant Cell Rep. 16:745-753.

10. Iwanami, T., and Ieki, H. 1996. Nucleotide sequence of 3 '-terminal region of RNA1 of citrus mosaic virus. Pages 201-207 in: Proc. Conf. IOCV, 13th. L. W. Timmer, P. Moreno, and R. K. Yokomi, eds. IOCV, Riverside, CA.

11. Iwanami, T., and Ieki, H. 1996. Nucleotide sequence of the coat protein genes of citrus mosaic virus. Virus Res. 42:181-186.

12. Iwanami, T., and Koizumi, M. 2000. Satsuma dwarf virus group. Page 59 in: Compendium of Citrus Diseases. L. W. Timmer, S. M. Garnsey, and J. H. Graham, eds. American Phytopathological Society, St. Paul, MN.

13. Iwanami, T., Koizumi, M., and Ieki, H. 1993.
Diversity of properties among Satsuma dwarf virus and related viruses. Ann. Phytopathol Soc. Jpn. 59:642-650.

14. Iwanami, T., Kondo, Y., Kobayashi, M., Han, S. S., and Karasev, A. V. 2001. Sequence diversity and interrelationships among isolates of satsuma dwarf-related viruses. Arch. Virol. 146:807-813.

15. Kaneyoshi (Hiramatsu), J., Kobayashi, S., Nakamura, Y., Shigemoto, N., and Doi, Y. 1994. A simple and efficient gene transfer system of trifoliate orange (Poncirus trifoliate Raf.). Plant Cell Rep. 13:541-545.

16. Mitushara, I., Ugaki, M., Hirochika, H., Ohshima, M., Murakami, T., Gotoh, Y., Katayose, Y., Nakamura, S., Honkura, R., Nishimiya, S., Ueno, K., Mochizuki, A., Tanimoto, H., Tsugawa, H., Otsuki, Y., and Ohashi, Y. 1996. Efficient promoter cassettes for enhanced expression of foreign genes in dicotyledonous and monocotyledonous plants. Plant Cell Physiol. 37:49-59.

17. Murray, M. G., and Thompson, W. F. 1980 Rapid isolation of high molecular weight plant DNA. Nucleic Acids Res. 8:4321-4325.

18. Nida, D. L., Anjos, J. R., Lomonossoff, G. P., and Ghabrial, S. A. 1992. Expression of cowpea mosaic virus coat protein precursor in transgenic tobacco plants. J. Gen. Virol. 73:157-163.

19. Prins, M., and Goldbach, R. 1996. RNA mediated virus resistance in transgenic plants. Arch. Virol. 141:2259-2276.

20. Reddy, M. S. S., Ghabrial, S. A., Redmond, C. T., Dinkins, R. D., and Collins, G. B. 2001 Resistance to Bean pod mottle virus in transgenic soybean lines expressing the capsid polyprotein. Phytopathology 91:831-838.

21. Sinisterra, X. H., Polston, J. E., Abouzid, A M., and Hiebert, E. 1999. Tobacco plants transformed with a modified coat protein of tomato mottle begomovirus show resistance to virus infection. Phytopathology 89:701-706.

22. Usugi, T., and Saito, Y. 1979. Satsuma dwarf virus. CMI/AAB Descriptions of Plant Viruses, No. 208.

23. Usugi, T., Yamamoto, S., and Tsuchizaki, T. 1986. Morphology, host range and serological properties of citrus mosaic virus causing mosaic diseases in satsuma mandarin. Ann. Phytopathol. Soc. Jpn. 52:349-354.

24. Wellink, J., Le Gall, O., Sanfacon, H., Ikegami, M., Jones, A. T. 2000. Family Comoviridae. Pages 691-701 in: Virus Taxonomy. Seventh Report of the International Committee on Taxonomy of Viruses. M. H. V. van Regenmortel, C. M. Fauquet, D. H. L. Bishop, E. B. Carstens, M. K. Estes, S. M. Lemon, J. Maniloff, M. A Mayo, D. J. McGeoch, C. R. Pringle, and R. B Wickner, eds. Academic Press, San Diego, CA. 